\title{
Genotip x Çevre İnteraksiyonunun Ekmeklik Buğdayda (T. aestivum L.) Bazı Kalite Özellikleri Üzerine Etkisi
}

\author{
*Turhan KAHRAMAN¹, İrfan ÖZTÜRK¹, Remzi AVCI ${ }^{1}$, Hüsnü AKTAȘ² \\ ${ }^{1}$ Trakya Tarımsal Araștırma Enstitüsü, Edirne \\ ${ }^{2}$ Mardin Artuklu Üniversitesi Kızlltepe Yüksek Okulu Kızıltepe, Mardin \\ *Sorumlu yazar e-posta (Corresponding author e-mail): turhankahraman@hotmail.com
}

\begin{abstract}
Öz
Bu araștırma, ekmeklik buğdayda bazı kalite kriterleri (bin tane ağıllğı, hektolitre ağırlığı, protein oranı, gluten miktarı, gluten indeksi ve zeleny sedimentasyon) üzerine; genotip, çevre ve genotip x çevre interaksiyonun etkilerini belirlemek amacıyla 2015-2016 yllında Edirne1, Edirne2, Keșan, Lüleburgaz ve Tekirdağ lokasyonlarında yürütülmüștür. Yirmi beș genotipten olușan deneme, (beș çeșit ve yirmi hat) Tesadüf Blokları Deneme Desenine göre dört tekerrürlü olarak yürütülmüștür. Araștırmada genotiplerin beș farklı çevredeki bin tane ağırlı̆ı, hektolitre ağırlığı, protein oranı, gluten, gluten indeksi ve zeleny sedimentasyonu incelenmiștir. Genotip, çevre ve genotip x çevre interaksiyonun incelenen tüm özellikler üzerine etkileri istatistiki olarak önemli bulunmuștur. Bu özellikler üzerine genotip ve çevre etkileri farklı düzeylerde olmuștur. Çevrenin sedimentasyona etkisi en az olurken, bin tane ve hektolitre ağırlığı üzerine etkisi en fazla olmuștur. Genotiplerin tüm lokasyonlardaki ortalama bin tane ağırlığl; 29.9-48.1 (39.71) g, hektolitre ağırlığ; 78.3-85.7 (81.84) kg/hl, protein oranı; \%10.0-12.9 (11.09), gluten miktarl; \%25.4-39.5 (32.20), gluten indeksi; \%18.8-93.1 (66.88), sedimentasyon ise 18.9-59.7 (41.03) ml arasında değișmiștir. İncelenen kalite özelliklerinden protein, gluten ve bin tane ağırlığı arasında önemli bir ilișki belirlenirken, diğer yandan da zeleny sedimentasyon, gluten indeks ve hektolitre ağırlığı arasında da önemli ilișki tespit edilmiștir. Protein, gluten ve bin tane ağırlığı yönünden 18, 25 ve 14 nolu genotipler ile Aldane çeșidi, zeleny sedimentasyon, gluten indeks ve hektolitre ağırlığı bakımından ise 7 nolu genotip en kaliteli olarak belirlenmiștir. Tekirdağ ve Edirne2 lokasyonları en kaliteli çevre, Edirne1 lokasyonu ise kalitesi en düșük çevre olarak belirlenmiștir. Tüm kalite özellikleri yönünden Aldane, 3, 7 ve 25 nolu genotipler en kaliteli, 21, 19 ve 4 nolu genotipler ise kalitesi en düșük genotipler olarak belirlenmiștir.
\end{abstract}

Anahtar Kelimeler: Ekmeklik buğday (T. aestivum L.); genotip; çevre; kalite

\section{The Effects of Genotype x Environment Interaction on Some Quality Assessments in Bread Wheat (T. aestivum L.)}

\section{Abstract}

The purpose of this study was to determine the effects of genotype, environment and variety $x$ environment interaction on some quality traits of bread wheat varieties. This research was carried out at Edirne1, Edirne2, Keșan, Lüleburgaz and Tekirdağ locations in 2015-16. Setting up with 25 varieties (5 check/control and 20 advanced lines), this study was conducted in a randomized complete block design technique with four replications. In the present research, thousand kernel weight, test weight, protein content, wet gluten content, gluten index, and zeleny sedimentation of the varieties were investigated at five different environments. The effects of genotype, environment and variety $x$ environment interaction on investigated properties were found statistically significant. These traits have been variously affected by varieties and environment. The environment has the lowest effect on test sedimentation, while the effect is highest on 1000 grain and test weight of the varieties. According to the average results, thousand kernel weight of genotypes obtained in all locations changed between 29.9-48.1 (39.7) g; test weight 78.3-85.7 (81.84) kg/hl, protein content; 10.0$12.9 \%$ (11.09), wet gluten; 25.4-39.5\% (32.20), gluten index; 18.8-93.1\% (66.88), and zeleny sedimentation 18.9-59.7 (41.03) $\mathrm{ml}$. There was a significant correlation between protein content, wet gluten and grain weight; on the other hand, the zeleny sedimentation, gluten index and test weight were found to be significantly related to each other. Number lines 18, 25, 14 and Aldane variety had the highest value in terms of protein content, wet gluten and grain weight; number line 7 has the lowest value in terms of zeleny sedimentation, gluten index and test weight. Tekirdağ and Edirne2 locations are obtained/determined as the environment with best quality and Edirne1 location as the lowest. Aldane, number lines 3, 7 and 25 had the highest, while number genotypes 21, 19 had the lowest value for observed characteristics.

Keywords: Bread wheat, genotype, environment, quality 


\section{Giriș}

$\mathrm{D}$ ünyada en fazla üretilen ve tüketilen hububat çeșidi buğdaydır. Buğday yılda yaklașı 620-680 milyon tonluk üretim ile dünyanın en önemli kültür bitkilerinden birisidir (Anonymous, 2013). Buğday kalitesi farklı faktörlerin etkisi ile değișen bir kavramdır. Buğday kalitesine etki eden faktörler, öncelikle çeșit ve çevre olup ikinci olarak depolama ve öğütme teknolojisidir. Buğdayın kalitesi üzerine etkili olan iklim, toprak ve çeșidin toplam etkisi değișken olup her birinin etkisini belirlemek çok zordur (Schiller et al. 1967; Elgün ve Ertugay, 1995). Buğday çeșit geliștirme programlarının birisi kaliteyi sabit tutarak veya iyileștirerek verimi artırmaktır. İkinci husus ise, tescile aday materyalin veya tescilli çeșidin değișik çevre koșullarında kalite düzeylerindeki değișimin belirlenmesinin gerekmesidir (Atlı, 1987).

Buğdayda tane verimi ile hektolitre ağırlı̆ı arasında, stres koșullarında ve verimin düșük olduğunda pozitif ve güçlü bir ilișki, çevre koșulları uygun ve verimler yüksek olduğunda ise negatif ve güçlü bir ilișkinin bulunduğu açıklanmıștır (Kelly et al. 1995). Buğdayda, hektolitre ağırlı̆ı üzerine çevrenin etkisi çeșitten daha fazla olmaktadır (Atlı, 1985). Buğday kalitesiyle ilgili yapılan çalıșmalarda, kullanılan çeșitlerin kalite düzeylerinde, yetiștirildikleri bölge ve șartlara göre farklılıklar bulunduğu belirlenmiștir (Altınbaș ve ark. 2004; Tayyar, 2005; Mut ve ark. 2007; Egesel ve ark. 2009). Protein miktarı, kalıtımın etkisinden çok, yetiștirme sürecindeki azotlu gübre uygulaması ve yağıș gibi çevresel faktörlerden etkilenmektedir (Atll, 1999). Genotip x çevre interaksiyonu önemli ölçüde genotipin, fenotipik yapısını etkilemektedir. Bir çeșidin farklı lokasyonlarda stabil bir durum göstermemesi, çeșit x çevre interaksiyonunun sonucudur (Jusuf et al. 2008).

Islah çalıșmaları sonucu geliștirilen yirmi hat ile beș standart çeșidin bazı kalite değerleri (bin tane ağırlı̆ı, hektolitre ağırlığı, protein oranı, gluten, gluten indeksi ve zeleny sedimentasyon) üzerine çeșit, çevre ve çeșit $x$ çevre interaksiyonlarının etkileri incelenerek, bölge için daha stabil ve kaliteli genotipleri belirlemek amacıyla araștırma yapılmıștır.

\section{Materyal ve Yöntem}

Denemede, Trakya Tarımsal Araștırma Enstitüsü ıslah çalıșmaları sonucu geliștirilen yirmi hat ve beș standart çeșit (Pehlivan, Selimiye, Gelibolu, Bereket ve Aldane) kullanılmıștır. Deneme, Tesadüf Blokları Deneme Deseni'ne göre dört tekerrürlü olarak, 2015-16 yılında Edirne1, Edirne2, Keșan, Lüleburgaz ve Tekirdağ lokasyonlarında yürütülmüștür.

Hasat sonrası fiziksel analizler, bin tane ağırlığı Özkaya ve Özkaya'ya (2005), hektolitre ağırlığı Anonymous'a (2009), kimyasal ve teknolojik analizlerden protein miktarı AACC Metod No: 46-30 (AACC 2000) metoduna, gluten ve gluten indeksi AACC Metod No: 3812A (AACC 2000) ve Zeleny-sedimentasyon (çökme) analizi ICC Standart No. 116-1 (ICC 2008) metoduna göre yapılmıștır.

\section{Bulgular ve Tartıșma}

Beș standart çeșit ile yirmi hattan olușan buğday genotiplerin incelenen kalite özellikleri (bin tane ağırlığı, hektolitre ağırlığı, protein oranı, gluten, gluten indeksi ve zeleny sedimentasyon) üzerine genotip, çevre ve genotip x çevre interaksiyonun etkileri önemli olmuștur.

Genotiplerin kalite değerlerinin, Altınbaș ve ark. (2004), Tayyar, (2005), Mut ve ark. (2007) ve Egesel ve ark. (2009)'nin yaptıkları çalıșmalarda olduğu gibi, kullanılan çeșitlerin kalite düzeylerinde, yetiștirildikleri lokasyonlara göre farklılıkları belirlenmiștir. Genotiplerin bin tane ağırlığı 26.0-58.3 g, tüm çevre ortalamadaki değerleri ise $29.9-48.1 \mathrm{~g}$ arasında değișmiștir. Bin tane ağırlığı yönünden elde ettiğimiz sonuçlar, Toklu ve ark. (1999), Demir ve ark. (1999), Altınbaș ve ark. (2004), Yağdı (2004) ve Kahraman ve ark. (2016)'nin çalıșmalarıyla kısmen benzerlik gösterirken, Ercan ve ark. (1988), Aydoğan ve ark. (2007), Aydın ve ark. (2005)'nin çalıșmalarıyla farklılık göstermiștir. Kaliteler arasındaki farklılık, kullanılan genotiplerin genetik yapısı ve çevre șartlarından kaynaklanmıștır. Aldane, Pehlivan çeșitleri ve 21 nolu genotip bin tane ağırlığı yönünden çevreden en az etkilenirken, 14 , 9,6 ve 3 nolu genotipler çevreden en çok etkilenmiștir. 
Çizelge 1. Yirmi beș buğday genotipine ait beș lokasyondaki bin tane ağırlığı ortalama değerleri ve olușturdukları gruplar

Table 1. Mean performance and LSD groups of 25 bread wheat genotypes for thousand kernel weight at 5 locations

\begin{tabular}{|c|c|c|c|c|c|c|c|}
\hline \multirow{2}{*}{ Genotip } & \multicolumn{5}{|c|}{ ÇEVRE } & \multicolumn{2}{|c|}{ GENOTIP } \\
\hline & Edirne1 & Edirne2 & Keșan & Lüleburgaz & Tekirdağ & Ortalaması & Etkisi \\
\hline 18 & $44.1 \mathrm{a}$ & $47.7 \mathrm{a}$ & $51.8 \mathrm{c}$ & $51.5 \mathrm{a}$ & $45.2 \mathrm{a}$ & $48.1 \mathrm{a}$ & 8.3 \\
\hline 19 & $41.1 \mathrm{~b}$ & $48.3 \mathrm{a}$ & $58.3 \mathrm{a}$ & 42.9 ef & $44.7 \mathrm{a}$ & $47.1 \mathrm{~b}$ & 7.4 \\
\hline Aldane (1) & $39.9 c$ & $46.1 \mathrm{~b}$ & $50.7 \mathrm{~d}$ & $48.3 b$ & $43.6 \mathrm{~b}$ & $45.7 \mathrm{c}$ & 6.0 \\
\hline 21 & $41.9 \mathrm{~b}$ & $42.1 \mathrm{~d}$ & $55.4 \mathrm{~b}$ & $39.8 \mathrm{ij}$ & $43.1 \mathrm{~b}$ & $44.5 \mathrm{~d}$ & 4.7 \\
\hline Pehlivan (15) & $36.8 \mathrm{~d}$ & $43.6 \mathrm{c}$ & $47.8 \mathrm{fg}$ & $50.8 \mathrm{a}$ & $42.4 \mathrm{c}$ & $44.3 \mathrm{~d}$ & 4.6 \\
\hline 24 & 34.6 ef & $48.0 \mathrm{a}$ & $50.2 \mathrm{~d}$ & $46.4 \mathrm{c}$ & $41.7 \mathrm{~d}$ & $44.2 \mathrm{~d}$ & 4.5 \\
\hline 25 & $34.9 \mathrm{e}$ & $42.2 \mathrm{~d}$ & $49.3 \mathrm{~d}$ & 43.2 ef & $39.9 \mathrm{e}$ & $41.9 \mathrm{e}$ & 2.2 \\
\hline 12 & $37.4 \mathrm{~d}$ & $41.9 \mathrm{~d}$ & $45.7 \mathrm{hl}$ & $44.3 \mathrm{~d}$ & $37.9 \mathrm{~g}$ & $41.4 \mathrm{f}$ & 1.7 \\
\hline 17 & 33.6 f-I & $39.9 \mathrm{e}$ & $48.0 \mathrm{fg}$ & $41.8 \mathrm{~g}$ & $38.7 \mathrm{f}$ & $40.4 \mathrm{~g}$ & 0.7 \\
\hline Selimiye (5) & 34.0 e-h & $39.6 \mathrm{e}$ & $44.3 \mathrm{jk}$ & $41.1 \mathrm{gh}$ & $41.5 \mathrm{~d}$ & $40.1 \mathrm{~g}$ & 0.4 \\
\hline 23 & 32.5 ij & $39.7 \mathrm{e}$ & 45.5 I & $42.6 \mathrm{f}$ & 35.9 I & $39.2 \mathrm{~h}$ & -0.5 \\
\hline 22 & $33.1 \mathrm{hl}$ & $38.5 \mathrm{f}$ & $43.3 \mathrm{~lm}$ & $43.6 \mathrm{de}$ & $36.6 \mathrm{~h}$ & 39.0 hı & -0.7 \\
\hline Gelibolu (20) & $33.7 \mathrm{f}-\mathrm{h}$ & 35.5 ij & $46.4 \mathrm{~h}$ & $44.0 \mathrm{~d}$ & $35.3 \mathrm{jk}$ & $39.0 \mathrm{hl}$ & -0.8 \\
\hline 14 & $39.9 \mathrm{c}$ & $34.6 \mathrm{jk}$ & 38.6 o & $39.2 \mathrm{jk}$ & $42.5 \mathrm{c}$ & 38.9 hı & -0.8 \\
\hline 11 & $37.1 \mathrm{~d}$ & $36.8 \mathrm{gh}$ & $45.1 \mathrm{ij}$ & $41.6 \mathrm{~g}$ & 33.81 & 38.9 hı & -0.8 \\
\hline 6 & $34.3 \mathrm{e}-\mathrm{g}$ & $36.0 \mathrm{hl}$ & $48.8 \mathrm{e}$ & $40.5 \mathrm{hl}$ & 34.01 & 38.7 I & -1.0 \\
\hline 9 & $31.6 \mathrm{j}$ & $36.8 \mathrm{gh}$ & 48.0 ef & $41.4 \mathrm{~g}$ & 35.7 ij & $38.7 \mathrm{I}$ & -1.0 \\
\hline 13 & 34.5 ef & 35.7 I & $43.9 \mathrm{kl}$ & 40.21 & $37.0 \mathrm{~h}$ & $38.3 \mathrm{j}$ & -1.5 \\
\hline Bereket (10) & $37.9 \mathrm{~d}$ & $34.2 \mathrm{k}$ & $42.7 \mathrm{~m}$ & $38.8 \mathrm{k}$ & $37.0 \mathrm{~h}$ & $38.1 \mathrm{j}$ & -1.6 \\
\hline 16 & $31.7 \mathrm{j}$ & $34.3 \mathrm{k}$ & $41.3 n$ & 37.21 & $36.9 \mathrm{~h}$ & $36.3 \mathrm{k}$ & -3.4 \\
\hline 8 & $31.6 \mathrm{j}$ & 33.01 & $43.1 \mathrm{Im}$ & 37.61 & $34.9 \mathrm{k}$ & $36.0 \mathrm{kl}$ & -3.7 \\
\hline 7 & 33.7 e-h & 35.6 I & $41.7 n$ & $34.7 n$ & $32.7 \mathrm{~m}$ & $35.7 \mathrm{Im}$ & -4.0 \\
\hline 3 & $33.2 \mathrm{~g}$ & $37.6 \mathrm{~g}$ & $37.2 p$ & $35.7 \mathrm{~m}$ & 33.51 & $35.4 \mathrm{~m}$ & -4.3 \\
\hline 2 & $27.4 \mathrm{k}$ & $32.5 I$ & $34.6 \mathrm{q}$ & $35.1 \mathrm{mn}$ & 35.7 ij & $33.1 \mathrm{n}$ & -6.7 \\
\hline 4 & 26.01 & $27.8 \mathrm{~m}$ & $33.1 \mathrm{r}$ & 32.3 o & $30.4 n$ & 29.90 & -9.8 \\
\hline Çevre Ort. & $35.05 \mathrm{e}$ & $38.72 \mathrm{c}$ & $45.38 \mathrm{a}$ & $41.37 \mathrm{~b}$ & $38.02 \mathrm{~d}$ & 39.71 & \\
\hline Çevre etkisi & -4.66 & -0.99 & 6.7 & 1.66 & -1.69 & - & \\
\hline CV (\%) & 2.07 & 1.45 & 1.12 & 1.11 & 0.84 & 1.34 & \\
\hline LSD & 1.19 & 0.92 & 0.84 & 0.75 & 0.53 & 0.38 & \\
\hline
\end{tabular}

Çevre: 0.35 , Genotip: 0.38, Genotip x Çevre: 0.86

Çizelge 2. Yirmi beș buğday genotipine ait beș lokasyondaki hektolitre ağırlığı ortalama değerleri ve olușturdukları gruplar

Table 2. Mean performance and LSD groups of 25 bread wheat genotypes for test weight at 5 locations

\begin{tabular}{|c|c|c|c|c|c|c|c|}
\hline \multirow{2}{*}{ Genotip } & \multicolumn{5}{|c|}{ ÇEVRE } & \multicolumn{2}{|c|}{ GENOTIP } \\
\hline & Edirne1 & Edirne2 & Keșan & Lüleburgaz & Tekirdağ & Ortalaması & Etkisi \\
\hline 7 & $85.3 \mathrm{a}$ & $85.8 \mathrm{a}$ & $88.9 \mathrm{a}$ & $83.9 \mathrm{a}$ & $84.5 \mathrm{a}$ & $85.7 \mathrm{a}$ & 3.81 \\
\hline Selimiye (5) & $84.6 \mathrm{~b}$ & $85.2 \mathrm{~b}$ & $87.5 \mathrm{bc}$ & $83.1 \mathrm{c}$ & $84.2 \mathrm{~b}$ & $84.9 \mathrm{~b}$ & 3.05 \\
\hline Pehlivan (15) & $83.9 c$ & $84.7 \mathrm{c}$ & $87.5 \mathrm{bc}$ & $83.5 b$ & $81.7 \mathrm{~g}$ & $84.3 \mathrm{c}$ & 2.41 \\
\hline 3 & $82.6 \mathrm{f}$ & $85.9 \mathrm{a}$ & $86.0 \mathrm{~d}$ & $83.3 \mathrm{c}$ & $82.5 \mathrm{f}$ & $84.0 \mathrm{~d}$ & 2.19 \\
\hline Gelibolu (20) & $83.7 \mathrm{de}$ & $82.2 \mathrm{~h}$ & 87.7 b & $82.1 \mathrm{e}$ & $82.9 \mathrm{~d}$ & $83.7 \mathrm{e}$ & 1.87 \\
\hline 18 & $83.9 \mathrm{c}$ & $84.1 \mathrm{e}$ & 85.3 e & $82.7 \mathrm{~d}$ & $82.5 \mathrm{f}$ & $83.7 \mathrm{e}$ & 1.85 \\
\hline 16 & $82.2 \mathrm{~h}$ & $82.9 \mathrm{~g}$ & $87.5 \mathrm{bc}$ & $82.5 \mathrm{~d}$ & $82.5 \mathrm{f}$ & $83.5 \mathrm{f}$ & 1.67 \\
\hline 17 & $83.6 \mathrm{e}$ & $84.4 \mathrm{~d}$ & 87.8 b & $79.7 \mathrm{~h}$ & 81.3 j & $83.3 \mathrm{~g}$ & 1.50 \\
\hline Aldane (1) & $82.5 \mathrm{f}$ & $83.2 \mathrm{f}$ & $85.9 d$ & $81.3 f$ & $83.3 \mathrm{c}$ & $83.2 \mathrm{~h}$ & 1.37 \\
\hline 25 & $82.4 \mathrm{fg}$ & $84.7 \mathrm{c}$ & 85.4 e & 81.9 e & $81.6 \mathrm{gh}$ & $83.2 \mathrm{~h}$ & 1.35 \\
\hline 8 & 81.9 I & 81.5 I & 87.2 c & $82.7 \mathrm{~d}$ & $82.7 \mathrm{e}$ & $83.2 \mathrm{~h}$ & 1.33 \\
\hline 24 & 81.6 j & $83.3 \mathrm{f}$ & $84.2 \mathrm{f}-\mathrm{h}$ & 81.9 e & $82.4 \mathrm{f}$ & 82.7 I & 0.83 \\
\hline Bereket (10) & $83.8 \mathrm{~cd}$ & $80.7 \mathrm{j}$ & $84.3 \mathrm{f}-\mathrm{h}$ & $79.8 \mathrm{~h}$ & $81.6 \mathrm{gh}$ & $82.0 \mathrm{j}$ & 0.17 \\
\hline 2 & $80.8 \mathrm{k}$ & 81.61 & $83.9 \mathrm{hl}$ & $80.3 \mathrm{~g}$ & $81.5 \mathrm{hl}$ & $81.6 \mathrm{k}$ & -0.25 \\
\hline 14 & $82.3 \mathrm{gh}$ & $80.7 \mathrm{j}$ & 83.5 ij & $80.1 \mathrm{~g}$ & 81.4 ij & $81.6 \mathrm{k}$ & -0.26 \\
\hline 11 & $82.5 \mathrm{f}$ & $82.1 \mathrm{~h}$ & $86.0 \mathrm{~d}$ & $78.5 \mathrm{k}$ & $78.8 \mathrm{~m}$ & $81.6 \mathrm{k}$ & -0.27 \\
\hline 4 & 80.21 & $79.9 k$ & $84.4 \mathrm{fg}$ & 79.4 । & $81.3 \mathrm{j}$ & 81.01 & -0.81 \\
\hline 12 & $79.6 \mathrm{~m}$ & 81.4 I & $84.1 \mathrm{gh}$ & $79.1 \mathrm{j}$ & $76.8 \mathrm{r}$ & $80.2 \mathrm{~m}$ & -1.65 \\
\hline 19 & 80.21 & $80.0 \mathrm{k}$ & $84.3 \mathrm{f}-\mathrm{h}$ & 73.10 & $80.9 k$ & $79.7 n$ & -2.15 \\
\hline 21 & $81.5 \mathrm{j}$ & $78.7 \mathrm{~m}$ & $84.7 \mathrm{f}$ & $71.5 p$ & 80.31 & 79.30 & -2.52 \\
\hline 6 & 78.20 & $80.0 \mathrm{k}$ & $84.4 \mathrm{fg}$ & $77.2 \mathrm{~m}$ & $76.8 r$ & 79.30 & -2.53 \\
\hline 13 & $79.0 n$ & 79.21 & 83.4 j & $76.4 n$ & 77.6 o & $79.1 p$ & -2.73 \\
\hline 22 & $77.2 p$ & $77.0 \mathrm{o}$ & 81.61 & $79.1 \mathrm{j}$ & $78.1 \mathrm{n}$ & $78.6 \mathrm{q}$ & -3.26 \\
\hline 23 & $76.4 \mathrm{q}$ & $78.6 \mathrm{~m}$ & $82.1 \mathrm{k}$ & $78.4 \mathrm{k}$ & $77.3 p$ & $78.5 q$ & -3.31 \\
\hline 9 & $77.3 p$ & $77.4 \mathrm{n}$ & $82.1 \mathrm{k}$ & 77.91 & $77.0 \mathrm{q}$ & $78.3 r$ & -3.51 \\
\hline Çevre Ort. & $81.47 \mathrm{c}$ & $81.79 b$ & $85.17 \mathrm{a}$ & $79.96 \mathrm{e}$ & $80.84 \mathrm{~d}$ & 81.84 & \\
\hline Çevre etkisi & -0.37 & -0.05 & 3.33 & -1.88 & -0.10 & - & \\
\hline Cे & 0.15 & 0.15 & 0.31 & 0.17 & 0.12 & 0.20 & \\
\hline LSD & 0.19 & 0.20 & 0.44 & 0.23 & 0.16 & 0.12 & \\
\hline
\end{tabular}

Çevre: 0.10 , Genotip: 0.12, Genotip x Çevre: 0.26 
Çizelge 3. Yirmi beș buğday genotipine ait beș lokasyondaki protein oranı ortalama değerleri ve olușturdukları gruplar

Table 3. Mean performance and LSD groups of 25 bread wheat genotypes for protein rate at 5 locations

\begin{tabular}{|c|c|c|c|c|c|c|c|}
\hline \multirow{2}{*}{ Genotip } & \multicolumn{5}{|c|}{ ÇEVRE } & \multicolumn{2}{|c|}{ GENOTIP } \\
\hline & Edirne1 & Edirne2 & Keșan & Lüleburgaz & Tekirdağ & Ortalaması & Etkisi \\
\hline 18 & $13.5 \mathrm{a}$ & $12.9 \mathrm{~b}$ & $13.2 \mathrm{a}$ & $12.0 \mathrm{c}$ & $12.8 \mathrm{a}$ & $12.9 \mathrm{a}$ & 1.78 \\
\hline Aldane (1) & $12.8 \mathrm{~b}$ & $13.6 \mathrm{a}$ & $12.7 \mathrm{c}$ & $13.0 \mathrm{a}$ & $12.0 \mathrm{~d}$ & $12.8 \mathrm{a}$ & 1.74 \\
\hline 3 & $12.5 \mathrm{c}$ & $12.8 \mathrm{~b}$ & $13.1 \mathrm{ab}$ & $12.5 \mathrm{~b}$ & $12.4 \mathrm{c}$ & $12.6 \mathrm{~b}$ & 1.54 \\
\hline 25 & $12.1 \mathrm{~d}$ & $12.6 \mathrm{c}$ & $12.9 \mathrm{~b}$ & $10.3 \mathrm{mn}$ & $12.9 \mathrm{a}$ & $12.2 \mathrm{c}$ & 1.07 \\
\hline 14 & $11.9 \mathrm{e}$ & $11.9 \mathrm{e}$ & $11.7 \mathrm{~d}$ & $11.7 \mathrm{~d}$ & $12.5 \mathrm{~b}$ & $11.9 \mathrm{~d}$ & 0.83 \\
\hline 2 & $11.5 \mathrm{fg}$ & $12.5 \mathrm{c}$ & $10.6 \mathrm{k}$ & $11.2 \mathrm{fg}$ & $10.9 \mathrm{~h}$ & $11.3 \mathrm{e}$ & 0.24 \\
\hline 22 & $11.5 \mathrm{fg}$ & $12.1 \mathrm{~d}$ & $11.1 \mathrm{fg}$ & $10.6 \mathrm{jk}$ & $11.3 \mathrm{f}$ & $11.3 \mathrm{e}$ & 0.22 \\
\hline 7 & $11.5 \mathrm{~g}$ & $11.8 \mathrm{e}$ & $11.2 \mathrm{f}$ & 11.3 ef & $10.5 \mathrm{j}$ & $11.2 \mathrm{f}$ & 0.16 \\
\hline 9 & $11.6 \mathrm{fg}$ & $11.0 \mathrm{hl}$ & $11.4 \mathrm{e}$ & 10.7 ij & $11.6 \mathrm{e}$ & $11.2 \mathrm{f}$ & 0.16 \\
\hline 23 & $11.6 \mathrm{f}$ & $11.4 \mathrm{f}$ & $10.7 \mathrm{jk}$ & $10.6 \mathrm{jk}$ & $11.4 \mathrm{f}$ & $11.1 \mathrm{~g}$ & 0.04 \\
\hline 24 & $12.0 \mathrm{~d}$ & $11.3 \mathrm{f}$ & $11.0 \mathrm{gh}$ & $9.6 \mathrm{q}$ & $11.7 \mathrm{e}$ & $11.1 \mathrm{~g}$ & 0.03 \\
\hline 19 & $11.1 \mathrm{~h}$ & $11.3 \mathrm{f}$ & $10.9 \mathrm{hl}$ & $11.4 \mathrm{e}$ & $10.5 \mathrm{j}$ & $11.0 \mathrm{~h}$ & -0.06 \\
\hline 6 & 10.9 ij & $11.1 \mathrm{gh}$ & $9.6 n$ & $11.0 \mathrm{~h}$ & $11.7 \mathrm{e}$ & I0.9 & -0.24 \\
\hline Pehlivan (15) & 11.0 & $11.3 \mathrm{f}$ & 10.8 ij & $10.6 \mathrm{jk}$ & $10.4 \mathrm{jk}$ & 10.8 ij & -0.29 \\
\hline 13 & $10.6 I$ & 10.7 j & $10.6 \mathrm{k}$ & $11.1 \mathrm{gh}$ & $10.9 \mathrm{~h}$ & $10.8 \mathrm{j}$ & -0.32 \\
\hline 21 & $10.6 I$ & $11.3 \mathrm{fg}$ & $9.9 \mathrm{Im}$ & $11.0 \mathrm{~h}$ & $10.4 \mathrm{jk}$ & $10.6 \mathrm{k}$ & -0.46 \\
\hline 17 & $10.2 n$ & $10.5 \mathrm{k}$ & $10.9 \mathrm{hl}$ & 10.8 & $10.8 \mathrm{~h}$ & $10.6 \mathrm{k}$ & -0.46 \\
\hline 11 & $10.4 \mathrm{~m}$ & $10.7 \mathrm{j}$ & $10.6 \mathrm{k}$ & 10.7 ij & $10.4 \mathrm{jk}$ & $10.6 I$ & -0.54 \\
\hline 12 & $10.7 \mathrm{kl}$ & $10.6 \mathrm{jk}$ & $10.6 \mathrm{k}$ & $10.5 \mathrm{kl}$ & $10.3 \mathrm{kl}$ & $10.5 I$ & -0.56 \\
\hline 8 & $10.8 \mathrm{jk}$ & $11.1 \mathrm{~h}$ & 10.8 ij & $10.0 p$ & $10.0 \mathrm{~m}$ & $10.5 \mid$ & -0.56 \\
\hline Selimiye (5) & 11.0 I & $10.5 \mathrm{k}$ & 9.40 & 10.1 op & $11.1 \mathrm{~g}$ & 10.4 m & -0.70 \\
\hline 4 & 11.0 I & $10.6 \mathrm{jk}$ & 9.40 & 10.2 no & $10.7 \mathrm{I}$ & $10.4 \mathrm{mn}$ & -0.74 \\
\hline 16 & $10.3 \mathrm{mn}$ & $10.7 \mathrm{j}$ & $10.0 I$ & $10.4 \mathrm{Im}$ & 10.31 & $10.3 n$ & -0.78 \\
\hline Gelibolu (20) & 9.80 & $10.9 i$ & $9.8 \mathrm{~m}$ & $10.5 \mathrm{kl}$ & $9.4 n$ & 10.10 & -1.02 \\
\hline Bereket (10) & 10.61 & 10.21 & $9.2 p$ & $9.7 \mathrm{q}$ & 10.21 & $10.0 p$ & -1.11 \\
\hline Çevre Ort. & $11.25 \mathrm{~b}$ & $11.41 \mathrm{a}$ & $10.87 \mathrm{~d}$ & $10.85 \mathrm{~d}$ & $11.07 \mathrm{c}$ & 11.09 & \\
\hline Çevre etkisi & 0.16 & 0.32 & -0.22 & -0.24 & -0.02 & - & \\
\hline Ć & 0.66 & 0.88 & 0.76 & 0.81 & 0.59 & 0.75 & \\
\hline LSD & 0.12 & 0.16 & 0.14 & 0.14 & 0.11 & 0.06 & \\
\hline
\end{tabular}

Çevre: 0.05, Genotip: 0.06, Genotip x Çevre: 0.13

Çizelge 4. Yirmi beș buğday genotipine ait beș lokasyondaki gluten miktarı ortalama değerleri ve olușturdukları gruplar

Table 4. Mean performance and LSD groups of 25 bread wheat genotypes for wet gluten content at 5 locations

\begin{tabular}{|c|c|c|c|c|c|c|c|}
\hline \multirow{2}{*}{ Genotip } & \multicolumn{5}{|c|}{ ÇEVRE } & \multicolumn{2}{|c|}{ GENOTIP } \\
\hline & Edirne1 & Edirne2 & Keșan & Lüleburgaz & Tekirdağ & Ortalaması & Etkisi \\
\hline 18 & $39.6 \mathrm{a}$ & $40.7 \mathrm{a}$ & $42.5 \mathrm{a}$ & $35.5 \mathrm{c}$ & $39.3 b$ & $39.5 \mathrm{a}$ & 7.31 \\
\hline 14 & $39.7 \mathrm{a}$ & $37.3 \mathrm{~d}$ & $36.2 \mathrm{c}$ & $37.5 \mathrm{a}$ & $41.1 \mathrm{a}$ & $38.3 b$ & 6.15 \\
\hline 25 & $37.7 \mathrm{~b}$ & $39.8 \mathrm{~b}$ & $38.9 \mathrm{~b}$ & $31.2 \mathrm{gh}$ & $39.6 \mathrm{~b}$ & $37.4 \mathrm{c}$ & 5.22 \\
\hline 3 & $38.0 \mathrm{~b}$ & $39.4 \mathrm{~b}$ & $36.9 \mathrm{c}$ & $36.0 \mathrm{~b}$ & $33.0 \mathrm{f}$ & $36.6 \mathrm{~d}$ & 4.45 \\
\hline Aldane (1) & $36.3 \mathrm{~cd}$ & $38.4 \mathrm{c}$ & $37.0 \mathrm{c}$ & $37.6 \mathrm{a}$ & $32.0 \mathrm{~g}$ & $36.2 \mathrm{e}$ & 4.05 \\
\hline 19 & $36.6 \mathrm{c}$ & $35.5 \mathrm{e}$ & $32.6 \mathrm{de}$ & $34.6 \mathrm{~d}$ & $32.0 \mathrm{~g}$ & $34.2 \mathrm{f}$ & 2.04 \\
\hline Pehlivan (15) & $32.1 \mathrm{f}$ & $36.8 \mathrm{~d}$ & $32.7 \mathrm{de}$ & $34.5 \mathrm{~d}$ & $33.7 \mathrm{e}$ & $33.9 \mathrm{f}$ & 1.75 \\
\hline 24 & $36.6 \mathrm{c}$ & $34.6 \mathrm{f}$ & $32.8 \mathrm{de}$ & $27.7 \mathrm{~m}$ & $34.8 \mathrm{c}$ & $33.3 \mathrm{~g}$ & 1.09 \\
\hline 9 & $35.6 \mathrm{~d}$ & $31.2 \mathrm{jk}$ & $33.4 \mathrm{~d}$ & $31.4 \mathrm{fg}$ & $34.2 \mathrm{~d}$ & $33.1 \mathrm{~g}$ & 0.94 \\
\hline 22 & $33.3 \mathrm{e}$ & 35.1 ef & 32.0 ef & 30.01 & $31.9 \mathrm{gh}$ & $32.4 \mathrm{~h}$ & 0.24 \\
\hline 2 & 32.8 ef & $37.9 c$ & 28.9 I-k & $30.9 \mathrm{~h}$ & $27.6 \mathrm{~m}$ & 31.6 I & -0.58 \\
\hline 23 & 32.7 ef & $31.7 \mathrm{j}$ & $31.1 \mathrm{fg}$ & 30.0 I & $32.6 \mathrm{f}$ & 31.61 & -0.60 \\
\hline Selimiye (5) & $32.4 \mathrm{f}$ & $33.0 \mathrm{~h}$ & $27.2 \mathrm{Im}$ & $31.7 \mathrm{f}$ & $31.5 \mathrm{~h}$ & $31.2 \mathrm{j}$ & -1.05 \\
\hline 8 & $31.1 \mathrm{~g}$ & $32.9 \mathrm{~h}$ & $32.8 \mathrm{de}$ & 28.7 I & $27.8 \mathrm{~m}$ & $30.7 \mathrm{k}$ & -1.55 \\
\hline 16 & $30.1 \mathrm{~h}$ & $32.8 \mathrm{hl}$ & $30.5 \mathrm{gh}$ & 29.9 ij & $29.9 j$ & $30.6 \mathrm{k}$ & -1.58 \\
\hline 7 & $31.3 \mathrm{~g}$ & $34.0 \mathrm{~g}$ & $30.9 \mathrm{fg}$ & $29.6 \mathrm{jk}$ & $26.7 n$ & $30.5 \mathrm{kl}$ & -1.72 \\
\hline 6 & $30.2 \mathrm{~h}$ & 32.31 & $25.1 n$ & $32.4 \mathrm{e}$ & $31.4 \mathrm{~h}$ & $30.3 \mathrm{~lm}$ & -1.92 \\
\hline 21 & $23.9 n$ & $37.9 \mathrm{c}$ & $28.0 \mathrm{kl}$ & $31.4 \mathrm{fg}$ & 30.0 ij & $30.2 \mathrm{Im}$ & -1.98 \\
\hline 17 & $28.7 \mathrm{k}$ & $31.0 \mathrm{k}$ & $30.8 \mathrm{fg}$ & 30.21 & 30.4 i & $30.2 \mathrm{Im}$ & -1.99 \\
\hline 13 & $29.0 \mathrm{k}$ & $31.5 \mathrm{jk}$ & $28.5 \mathrm{jk}$ & $31.3 \mathrm{fg}$ & $29.9 \mathrm{j}$ & $30.0 \mathrm{mn}$ & -2.18 \\
\hline 12 & 29.8 ij & 30.21 & ו- $30.0 \mathrm{~g}$ & 30.0 ij & $29.2 \mathrm{k}$ & 29.8 no & -2.37 \\
\hline 11 & $29.3 \mathrm{jk}$ & $31.0 \mathrm{k}$ & $30.4 \mathrm{gh}$ & 30.11 & 28.41 & 29.8 no & -2.39 \\
\hline Bereket (10) & $30.8 \mathrm{gh}$ & $31.3 \mathrm{jk}$ & $29.6 \mathrm{~h}-\mathrm{j}$ & $26.0 n$ & $30.1 \mathrm{ij}$ & 29.60 & -2.65 \\
\hline Gelibolu (20) & $26.0 \mathrm{~m}$ & $31.1 \mathrm{jk}$ & $26.1 \mathrm{mn}$ & $29.3 \mathrm{k}$ & $29.3 \mathrm{k}$ & $28.3 p$ & -3.85 \\
\hline 4 & 27.01 & $27.2 \mathrm{~m}$ & 21.50 & $25.7 n$ & 25.6 o & $25.4 \mathrm{q}$ & -6.81 \\
\hline Çevre Ort. & $32.41 \mathrm{~b}$ & $34.16 \mathrm{a}$ & $31.45 \mathrm{~d}$ & $31.32 \mathrm{e}$ & $31.67 \mathrm{c}$ & 32.20 & \\
\hline Çevre etkisi & 0.21 & 1.96 & -0.75 & -0.53 & -0.53 & & \\
\hline ĆV (\%) & 1.49 & 1.05 & 2.28 & 0.78 & 0.94 & 1.41 & \\
\hline LSD & 0.79 & 0.59 & 1.18 & 0.40 & 0.49 & 0.33 & \\
\hline
\end{tabular}

Çevre: 0.12, Genotip: 0.33, Genotip x Çevre: 0.73 
Genotiplerin hektolitre ağırlığı 71.5-88.9 $\mathrm{kg} / \mathrm{hl}$, genotiplerin tüm çevrelerdeki ortalama hektolitre ağırlığı 78.3-85.7 kg/hl, çevre olarak en yüksek hektolitre ağırlığı $85.2 \mathrm{~kg} / \mathrm{hl}$ ile Keșan, genotip olarak ise $88.9 \mathrm{~kg} / \mathrm{hl}$ ile 7 nolu hattan elde edilmiștir. Hektolitre ağırlığı yönünden elde ettiğimiz sonuçlar, Demir ve ark. (1999), Kahraman ve ark. (2016)'nin çalıșmalarıyla kısmen benzerlik gösterirken Toklu ve ark. (1999), Yağdı (2004) ve Aydın ve ark. (2005)'nın çalıșmalarıyla farklııık göstermiștir. Sekiz ve 16 nolu genotipler ile Gelibolu çeșidi hektolitre ağırlığı yönünden çevreden en az etkilenirken, 21,19 ve 6 nolu genotipler çevreden en çok etkilenmiștir.

Genotiplerin protein oranı \%9.2-13.6, genotiplerin tüm çevrelerdeki ortalama protein değerleri ise \%10.0-12.9, çevre olarak en yüksek protein oranı \%11.41 ile Edirne2, genotip olarak ise \%13.6 ile Aldane çeșidinden elde edilmiștir. Genetik ve yetișme koșullarına bağlı olarak buğdaydaki protein miktarı \%7-14 arasında değișmektedir.

Genotiplerin protein oranı yönünden elde ettiğimiz sonuçlar, Toklu ve ark. (1999), Aydın ve ark. (2005) ve Kahraman ve ark. (2016)'nin çalıșmalarıyla kısmen benzerlik gösterirken, Ercan ve ark. (1988), Demir ve ark. (1999), Yağdı (2004) ve Aydoğan ve ark. (2007)'nın çalıșmalarıyla farklılık göstermiștir. Aldane çeșidi ile 18 nolu genotip protein yönünden çevreden en az etkilenirken, 22, 24, 2, 11 ve 4 nolu genotipler çevreden en çok etkilenmiștir.

Genotiplerin gluten miktarı \%21.5-42.5, genotiplerin tüm çevrelerdeki ortalama gluten miktarları ise \%25.4-39.5, çevre olarak en yüksek gluten miktarı \%34.16 ile Edirne2, genotip olarak ise $\% 42.5$ ile 18 nolu genotipten elde edilmiștir. Genotiplerin gluten miktarı yönünden elde ettiğimiz sonuçlar, Demir ve ark. (1999), Yağdı (2004), Altınbaș ve ark. (2004) ve Kahraman ve ark. (2016)'nın çalıșmalarıyla kısmen benzerlik göstermiștir. Çevre olarak en düșük gluten \%31.32 ile Lüleburgazda elde edilmiștir (Çizelge 4). Pehlivan çeșidi gluten yönünden çevreden en az etkilenirken, 14, 17,12 ve 7 nolu genotipler çevreden en çok etkilenmiștir.

Genotiplerin gluten indeksi \%7.0-95.5, genotiplerin tüm çevrelerdeki ortalama gluten indeksi ise \%18.8-93.1, çevre olarak en yüksek gluten indeksi \%76.11 ile Tekirdağ, genotip olarak ise \%95.5 ile 7 nolu genotipten elde edilmiștir. Genotiplerin gluten miktarı yönünden elde ettiğimiz sonuçlar, Demir ve ark. (1999) ve Kahraman ve ark. (2016)'nın çalıșmalarıyla kısmen benzerlik göstermiștir. Gluten indeksi; glutenin kalitesini gösterip, onun kuvvetini belirtmektedir. Çevre olarak en düșük gluten indeksi \%59.45 ile Edirne1'de elde edilmiștir (Çizelge 5). Gluten indeksi yönünden çevreden 17, 3 ve 8 nolu genotipler en az, 2, 4, 1, 18, 5 ve 24 nolu genotipler en çok etkilenmiștir.

Genotiplerin zeleny sedimentasyon değeri $16.7-65.0 \mathrm{ml}$, genotiplerin tüm çevrelerdeki ortalama zeleny sedimentasyonu ise 18.9$59.7 \mathrm{ml}$, çevre olarak en yüksek zeleny sedimentasyon $65.0 \mathrm{ml}$ Aldane $44.21 \mathrm{ml}$ ile Tekirdağ, genotip olarak ise $65.0 \mathrm{ml}$ ile Aldane çeșidinden elde edilmiștir.

Genotiplerin sedimentasyon sonuçları, Aydın ve ark. (2005) ve Kahraman ve ark. (2016)'nin çalıșmalarıyla kısmen benzerlik gösterirken, Demir ve ark. (1999)'nın çalıșmalarıyla farklılık göstermiștir. Sedimentasyon; protein kalitesini belirtmekte ve yüksek olması kalitenin yüksek olduğunu göstermektedir.

Çevre olarak en düșük zeleny sedimentasyon $39.36 \mathrm{ml}$ ile Edirne1 çevresinde elde edilmiștir (Çizelge 6). Onaltı ve 13 nolu genotipler zeleny sedimentasyon yönünden çevreden en az etkilenirken, 25, 24, 9 ve 7 nolu genotipler çevreden en çok etkilenmiștir. Genotiplerin 1000 tane ve hektolitre ağırlığı yönünden en yüksek değerler Keșan lokasyonu, zeleny sedimentasyon ve gluten indeks yönünden Tekirdağ lokasyonu, gluten ve protein yönünden ise Edirne1 ve Edirne2 lokasyonlarında elde edilmiștir (Șekil 1).

Protein, gluten ve bin tane ağırığı yönünden 18,25 ve 14 nolu genotipler ile Aldane çeșidi, zeleny sedimentasyon, gluten indeks ve hektolitre ağırlığı bakımından ise 7 nolu genotip en kaliteli olarak belirlenmiștir (Șekil 2.). Tüm kalite özellikleri yönünden Aldane, 3 , 7 ve 25 nolu genotipler en kaliteli, 21, 19 ve 4 nolu genotipler ise kalitesi en düșük genotipler olarak belirlenmiștir. 
Çizelge 5. Yirmi beș buğday genotipine ait beș lokasyondaki gluten indeksi ortalama değerleri ve olușturdukları gruplar

Table 1. Mean performance and LSD groups of 25 bread wheat genotypes for gluten index at 5 locations

\begin{tabular}{|c|c|c|c|c|c|c|c|}
\hline \multirow{2}{*}{ Genotip } & \multicolumn{5}{|c|}{ ÇEVRE } & \multicolumn{2}{|c|}{ GENOTIP } \\
\hline & Edirne1 & Edirne2 & Keșan & Lüleburgaz & Tekirdağ & Ortalaması & Etkisi \\
\hline 7 & $91.1 \mathrm{ab}$ & $92.2 \mathrm{a}$ & $93.5 \mathrm{a}$ & $93.4 \mathrm{a}$ & $95.5 \mathrm{ab}$ & $93.1 \mathrm{a}$ & 26.25 \\
\hline Aldane (1) & $94.3 \mathrm{a}$ & $88.6 \mathrm{a}$ & $87.2 \mathrm{a}-\mathrm{c}$ & $85.0 \mathrm{bc}$ & $93.3 \mathrm{a}-\mathrm{c}$ & $89.7 \mathrm{~b}$ & 22.80 \\
\hline Gelibolu (20) & $85.0 \mathrm{~cd}$ & $77.1 \mathrm{~cd}$ & $91.8 \mathrm{a}$ & $85.8 \mathrm{bc}$ & $85.8 \mathrm{c}-\mathrm{e}$ & $85.1 \mathrm{c}$ & 18.21 \\
\hline 13 & $85.5 \mathrm{bc}$ & $78.9 \mathrm{bc}$ & $88.3 \mathrm{ab}$ & $80.9 \mathrm{~cd}$ & 91.6 a-d & $85.0 \mathrm{c}$ & 18.13 \\
\hline 3 & $80.2 \mathrm{c}-\mathrm{f}$ & $75.1 \mathrm{c}-\mathrm{e}$ & $88.9 \mathrm{ab}$ & $83.3 b-d$ & $94.7 \mathrm{ab}$ & $84.4 \mathrm{c}$ & 17.55 \\
\hline 8 & $79.5 \mathrm{~d}-\mathrm{f}$ & $74.5 \mathrm{c}-\mathrm{e}$ & $77.4 \mathrm{~d}$ & $89.9 \mathrm{ab}$ & $95.5 \mathrm{ab}$ & $83.3 \mathrm{~cd}$ & 16.46 \\
\hline 16 & $82.4 \mathrm{c}-\mathrm{e}$ & $72.4 \mathrm{de}$ & $82.1 \mathrm{~b}-\mathrm{d}$ & $85.1 \mathrm{bc}$ & $93.8 \mathrm{ab}$ & $83.1 \mathrm{~cd}$ & 16.27 \\
\hline 12 & $75.0 \mathrm{fg}$ & $82.3 \mathrm{~b}$ & 84.7 a-d & $81.9 \mathrm{~cd}$ & 90.9 a-d & $83.0 \mathrm{~cd}$ & 16.08 \\
\hline 17 & $79.4 \mathrm{~d}-\mathrm{f}$ & $71.7 \mathrm{de}$ & $78.4 \mathrm{~cd}$ & $79.9 \mathrm{~cd}$ & $94.7 \mathrm{ab}$ & $80.8 \mathrm{de}$ & 13.96 \\
\hline 6 & $73.4 \mathrm{gh}$ & $74.6 \mathrm{c}-\mathrm{e}$ & $92.5 \mathrm{a}$ & $76.9 \mathrm{~d}$ & $85.5 \mathrm{de}$ & $80.6 \mathrm{de}$ & 13.67 \\
\hline 11 & 65.41 & $73.0 \mathrm{de}$ & $76.1 \mathrm{~d}$ & $85.5 \mathrm{bc}$ & 90.7 a-d & 78.1 ef & 11.23 \\
\hline Bereket (10) & $68.5 \mathrm{hl}$ & $53.0 \mathrm{hı}$ & $85.1 \mathrm{a}-\mathrm{d}$ & $84.4 \mathrm{bc}$ & 87.9 b-d & $75.8 \mathrm{fg}$ & 8.91 \\
\hline 2 & 53.2 j & $56.8 \mathrm{gh}$ & $78.0 \mathrm{~cd}$ & $90.1 \mathrm{ab}$ & $91.1 \mathrm{a}-\mathrm{d}$ & $73.8 \mathrm{gh}$ & 6.95 \\
\hline Selimiye (5) & $77.2 \mathrm{e}-\mathrm{g}$ & $44.0 \mathrm{jk}$ & $65.9 \mathrm{e}$ & $77.4 \mathrm{~d}$ & 96.7 a & $72.2 \mathrm{~h}$ & 5.35 \\
\hline 25 & 53.2 j & $62.6 \mathrm{f}$ & $55.5 \mathrm{f}$ & $82.4 \mathrm{~cd}$ & $78.3 \mathrm{e}$ & 66.4 I & -0.49 \\
\hline 4 & $47.3 \mathrm{kl}$ & $41.3 \mathrm{k}$ & $77.8 \mathrm{~cd}$ & $69.5 \mathrm{e}$ & $78.2 \mathrm{e}$ & $62.8 \mathrm{j}$ & -4.09 \\
\hline 23 & $45.5 I$ & $58.4 \mathrm{fg}$ & $47.4 \mathrm{fg}$ & $54.0 \mathrm{f}$ & $66.5 \mathrm{f}$ & $54.3 \mathrm{k}$ & -12.53 \\
\hline 9 & 41.9 I & $63.0 \mathrm{e}$ & $47.9 \mathrm{fg}$ & $53.9 \mathrm{f}$ & $64.2 \mathrm{f}$ & $54.2 \mathrm{k}$ & -12.72 \\
\hline 24 & $27.3 \mathrm{mn}$ & 48.5 ij & 56.9 ef & $69.1 \mathrm{e}$ & $61.9 \mathrm{fg}$ & $52.7 \mathrm{k}$ & -14.15 \\
\hline 22 & $32.4 \mathrm{~m}$ & 51.21 & $53.8 \mathrm{fg}$ & $53.8 \mathrm{f}$ & $68.3 \mathrm{f}$ & $51.9 \mathrm{k}$ & -15.00 \\
\hline 18 & 52.5 jk & $41.0 \mathrm{k}$ & $44.8 \mathrm{~g}$ & $53.6 \mathrm{f}$ & $46.8 \mathrm{~h}$ & 47.7 I & -19.15 \\
\hline 14 & $30.5 \mathrm{mn}$ & 48.7 ij & $49.4 \mathrm{fg}$ & $43.9 \mathrm{~g}$ & $54.5 \mathrm{gh}$ & 45.41 & -21.49 \\
\hline Pehlivan (15) & $29.8 \mathrm{mn}$ & $42.2 \mathrm{k}$ & $52.3 \mathrm{fg}$ & $39.9 \mathrm{~g}$ & 37.9 I & $40.4 \mathrm{~m}$ & -26.47 \\
\hline 19 & 26.0 n & 26.51 & $34.8 \mathrm{~h}$ & $28.2 \mathrm{~h}$ & ز & $29.4 n$ & -37.53 \\
\hline 21 & 10.00 & 27.41 & 22.11 & 7.01 & $27.4 \mathrm{j}$ & 18.80 & -48.10 \\
\hline Çevre Ort. & $59.45 \mathrm{~d}$ & $60.99 \mathrm{c}$ & $68.49 \mathrm{~b}$ & $69.39 \mathrm{~b}$ & $76.11 \mathrm{a}$ & 66.88 & \\
\hline Çevre etkisi & -7.43 & -5.89 & 1.61 & 2.51 & 9.23 & - & \\
\hline $\mathrm{C}^{3} \mathrm{~V}(\%)$ & 5.95 & 4.79 & 8.44 & 5.98 & 6.24 & 6.49 & \\
\hline LSD & 5.81 & 4.80 & 9.48 & 6.81 & 7.80 & 3.12 & \\
\hline
\end{tabular}

Çevre: 1.25, Genotip: 3.12, Genotip x Çevre: 6.98

Çizelge 6. Yirmi beș buğday genotipine ait beș lokasyondaki sedimentasyon (zeleny) ortalama değerleri ve olușturdukları gruplar

Table 6. Mean performance and LSD groups of 25 bread wheat genotypes for zeleny sedimentation at 5 locations

\begin{tabular}{|c|c|c|c|c|c|c|c|}
\hline \multirow{2}{*}{ Genotip } & \multicolumn{5}{|c|}{ ÇEVRE } & \multicolumn{2}{|c|}{ GENOTIP } \\
\hline & Edirne1 & Edirne2 & Keșan & Lüleburgaz & Tekirdağ & Ortalaması & Etkisi \\
\hline Aldane (1) & $57.7 \mathrm{a}$ & $65.0 \mathrm{a}$ & $56.0 \mathrm{a}$ & $63.0 \mathrm{a}$ & $56.7 \mathrm{~b}$ & $59.7 \mathrm{a}$ & 18.64 \\
\hline 7 & $55.0 \mathrm{~b}$ & $60.7 \mathrm{~b}$ & $56.0 \mathrm{a}$ & $53.0 \mathrm{~b}$ & $55.7 \mathrm{bc}$ & $56.1 \mathrm{~b}$ & 15.04 \\
\hline 3 & $58.7 \mathrm{a}$ & $49.7 \mathrm{c}$ & $54.0 \mathrm{~b}$ & $52.0 \mathrm{~b}$ & $62.0 \mathrm{a}$ & $55.3 \mathrm{c}$ & 14.24 \\
\hline 25 & $44.7 \mathrm{e}$ & $48.7 \mathrm{~d}$ & $53.0 \mathrm{~b}$ & $43.7 \mathrm{gh}$ & $61.0 \mathrm{a}$ & $50.2 \mathrm{~d}$ & 9.17 \\
\hline 8 & $49.7 \mathrm{c}$ & $49.0 \mathrm{~cd}$ & $48.7 \mathrm{c}$ & $44.0 \mathrm{fg}$ & $55.0 \mathrm{c}$ & $49.3 \mathrm{e}$ & 8.24 \\
\hline 16 & $48.0 \mathrm{~d}$ & $44.7 \mathrm{~g}$ & $45.0 \mathrm{de}$ & $46.0 \mathrm{de}$ & $51.0 \mathrm{~d}$ & $46.9 \mathrm{f}$ & 5.90 \\
\hline 13 & $44.0 \mathrm{e}$ & $48.7 \mathrm{~d}$ & 44.0 ef & $46.7 \mathrm{~d}$ & $49.7 \mathrm{e}$ & $46.6 \mathrm{f}$ & 5.57 \\
\hline 17 & $41.0 \mathrm{f}$ & $43.7 \mathrm{~h}$ & $45.7 \mathrm{~d}$ & 45.0 ef & $49.7 \mathrm{e}$ & $45.0 \mathrm{~g}$ & 3.97 \\
\hline 6 & $43.7 \mathrm{e}$ & $46.0 \mathrm{f}$ & $42.7 \mathrm{~g}$ & $43.7 \mathrm{gh}$ & $45.7 \mathrm{fg}$ & $44.3 \mathrm{~h}$ & 3.30 \\
\hline 2 & $40.0 \mathrm{fg}$ & 46.7 ef & 39.0 ij & $50.7 \mathrm{c}$ & $45.0 \mathrm{f}-\mathrm{h}$ & $44.3 \mathrm{~h}$ & 3.24 \\
\hline 12 & $41.0 \mathrm{f}$ & $47.0 \mathrm{e}$ & $40.7 \mathrm{~h}$ & $43.7 \mathrm{gh}$ & $44.7 \mathrm{gh}$ & 43.4 I & 2.37 \\
\hline 11 & $38.0 \mathrm{~h}$ & 42.7 I & 44.0 ef & 45.0 ef & $44.0 \mathrm{hl}$ & $42.7 \mathrm{j}$ & 1.70 \\
\hline Gelibolu (20) & 36.0 I & $44.0 \mathrm{gh}$ & $40.0 \mathrm{hl}$ & $42.7 \mathrm{~h}$ & $40.3 \mathrm{j}$ & $40.6 \mathrm{k}$ & -0.43 \\
\hline 14 & $38.0 \mathrm{~h}$ & $39.7 \mathrm{j}$ & 39.7 hı & 38.7 I & $44.0 \mathrm{hl}$ & 40.01 & -1.03 \\
\hline Selimiye (5) & $39.0 \mathrm{gh}$ & $37.0 \mathrm{k}$ & 32.01 & $44.0 \mathrm{fg}$ & $46.0 \mathrm{f}$ & $39.6 \mathrm{Im}$ & -1.43 \\
\hline 18 & $40.7 \mathrm{f}$ & $37.7 \mathrm{k}$ & $43.0 \mathrm{fg}$ & $36.7 \mathrm{j}$ & $38.7 \mathrm{k}$ & $39.3 \mathrm{~m}$ & -1.70 \\
\hline 24 & $34.7 \mathrm{j}$ & $35.0 \mathrm{~m}$ & $39.7 \mathrm{hl}$ & 31.7 I & $44.0 \mathrm{~h}$ & $37.0 \mathrm{n}$ & -4.03 \\
\hline 9 & $32.7 \mathrm{k}$ & $35.0 \mathrm{~m}$ & 39.0 ij & $33.7 \mathrm{k}$ & 43.0 I & $36.7 n$ & -4.36 \\
\hline Bereket (10) & $39.0 \mathrm{gh}$ & 36.01 & $30.0 \mathrm{~m}$ & $34.7 \mathrm{k}$ & $41.0 \mathrm{j}$ & 36.10 & -4.90 \\
\hline Pehlivan (15) & 31.01 & 36.01 & $36.7 \mathrm{k}$ & 38.0 I & 36.01 & $35.5 p$ & -5.50 \\
\hline 23 & $34.7 \mathrm{j}$ & 30.7 o & $38.0 \mathrm{j}$ & 32.01 & $39.0 \mathrm{k}$ & $34.9 \mathrm{q}$ & -6.16 \\
\hline 22 & $32.7 \mathrm{k}$ & $33.0 n$ & $36.0 \mathrm{k}$ & 32.01 & $38.7 \mathrm{k}$ & $34.5 q$ & -6.56 \\
\hline 4 & $27.7 \mathrm{~m}$ & $28.7 p$ & $24.7 n$ & $29.0 \mathrm{~m}$ & $30.0 \mathrm{~m}$ & $28.0 r$ & -13.03 \\
\hline 19 & $20.0 n$ & $19.0 \mathrm{q}$ & 20.7 o & $22.7 n$ & $22.3 n$ & $20.9 \mathrm{~s}$ & -20.10 \\
\hline 21 & 16.7 o & $19.7 \mathrm{q}$ & $18.0 \mathrm{p}$ & 18.0 o & $22.3 n$ & $18.9 \mathrm{t}$ & -22.10 \\
\hline Çevre Ort. & $39.36 \mathrm{~d}$ & $40.95 \mathrm{~b}$ & $40.24 \mathrm{c}$ & $40.40 \mathrm{c}$ & $44.21 \mathrm{a}$ & 41.03 & \\
\hline Çevre etkisi & -1.67 & -0.8 & -0.79 & -0.63 & 3.18 & & \\
\hline Č (\%) & 1.64 & 1.31 & 1.60 & 1.71 & 1.40 & 1.53 & \\
\hline LSD & 1.06 & 0.88 & 1.06 & 1.14 & 1.02 & 0.45 & \\
\hline
\end{tabular}

Çevre: 0.19, Genotip: 0.45, Genotip x Çevre: 1.01 


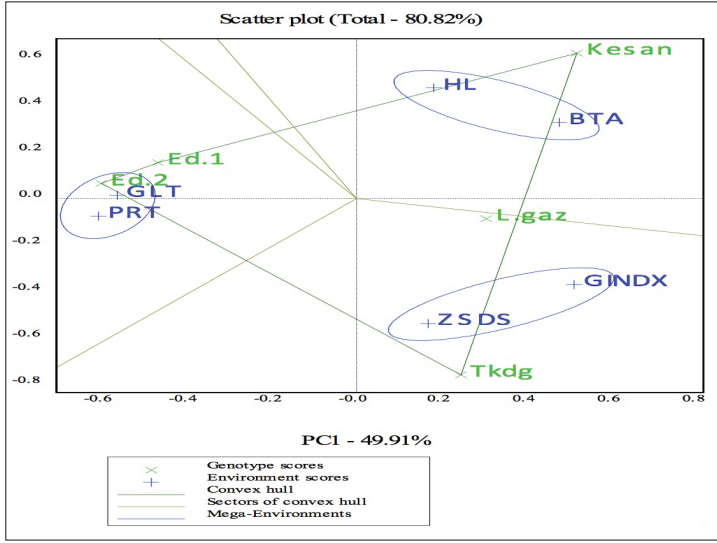

Șekil 1. Yirmi beș buğday genotipin beș çevre ve kalite ilișkileri

Figure 1. Quality relationship and mean of 25 bread wheat genotypes at 5 loc.

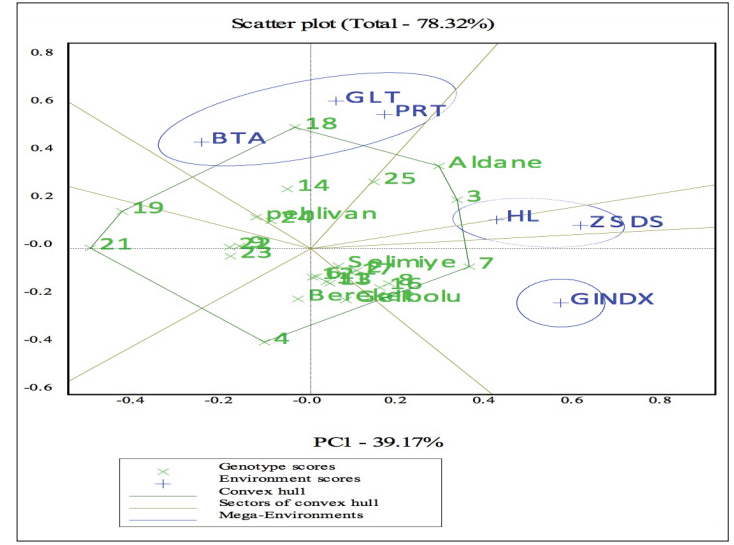

Șekil 2. Yirmi beș buğday genotipin beș çevre kalite ortalamaları

Figure 2. Quality parameters mean of 25 bread wheat genotypes at 5 loc.

Çizelge 7. Kalite karakterlerinin her biri için toplam varyasyonun lokasyon, genotip ve lokasyon x genotip tarafından temsiliyeti (\%)

Table 7. Total variation is represented by location, genotype and location $x$ genotype (\%) for each of the quality characters is represented

\begin{tabular}{lcccccc}
\hline Kaynak & 1000 Tane Ağ. & Hektolitre Ağ. & Protein & Gluten & Gluten İnd. & Zeleny sedim \\
\hline Lok (Çevre) & 34.3 & 34.0 & 5.2 & 7.0 & 7.5 & 2.7 \\
T[L]\&Rnd & 0.1 & 0.0 & 0.1 & 0.0 & 0.1 & 0.0 \\
Çeşit & 49.9 & 49.5 & 72.4 & 68.4 & 79.1 & 89.4 \\
Çeș*Lok & 15.2 & 16.3 & 21.8 & 23.8 & 10.9 & 7.6 \\
\hline Toplam & 99.5 & 99.8 & 99.5 & 99.2 & 97.5 & 99.8
\end{tabular}

Genel olarak kalite karakterlerindeki varyasyonun büyük bir kısmı çevre tarafından temsil edilirken, bu çalıșmada genotipin etkisinin toplam varyasyondaki oranı daha yüksek olmuștur.

Çevrenin kalite karakterlerine etkisi \%2.734.3 arasında olmuștur. 1000 tane ve hektolitre ağırlı̆ı̆ üzerine çevrenin etkileri $\% 34.3$ ve \%34.0 ile en yüksek olurken, \%2.7 ile zeleny sedimentasyon üzerine etkisi en düșük olmuștur. Çeșidin kalite özelliklerine etkisi \%49.5-89.4 arasında olmuștur. Çeșidin zeleny sedimentasyon üzerine etkisi \%89.4 ile en fazla olurken, \%49.9 ile 1000 tane ağırlığı ve \%49.5 ile hektolitre ağırlığına en az etkisi olmuștur. Çeșit X Genotip interaksiyonunun kalite değerleri üzerine etkisi \%7.6-23.8 arasında olmuștur. Genotip x çevre etkisi \%23.8 ile en fazla gluten üzerinde olurken, \%7.6 ile en az sedimentasyon üzerinde olmuștur.

\section{Sonuç}

Çevrenin bin tane ve hektolitre ağırlığı üzerine etkileri en yüksek olurken, zeleny sedimentasyon üzerine etkisi en düșük olmuștur. Çeșidin zeleny sedimentasyon üzerine etkisi en fazla olurken, bin tane ağırlığı ve hektolitre ağırlığına en az etkileșmiștir. Protein, gluten ve bin tane ağırlığı yönünden 18, 25 ve 14 nolu genotipler ile Aldane çeșidi, zeleny sedimentasyon, gluten indeks ve hektolitre ağırlığı bakımından ise 7 nolu genotip en kaliteli olarak belirlenmiștir. Tekirdağ ve Edirne2 lokasyonları en kaliteli çevre, Edirne1 lokasyonu ise kalitesi en düșük çevre olarak belirlenmiștir. Tüm kalite özellikleri yönünden Aldane, 3,7 ve 25 nolu genotipler en kaliteli, 21,19 ve 4 nolu genotipler ise kalitesi en düșük genotipler olarak belirlenmiștir.

\section{Kaynaklar}

Altınbaș M., Tosun M., Yüce S., Konak C., Köse E., A. ve Akçalı Can R., 2004. Ekmeklik Buğdayda (T. aestivum L.) Dane Verimi ve Bazı Kalite Özellikleri Üzerinde Genotip ve Lokasyon Etkileri, Ege Üniversitesi Ziraat Fakültesi Dergisi, 41(1): $65-74$

Anonim, 1990. AACC standard 55-30 American Association of Cereal Chemists 
Anonymous, 2013. FAO Statistics Division, FAOSTAT-Agriculture, http://www.fao.org/ faostat (Erișim tarih: 21.01.2016)

Atı A., 1987. Kıșlık Tahıl Üretim Bölgelerimizde Yetiștirilen Bazı Ekmeklik ve Makarnalık Buğday Çeșitlerinin Kaliteleri ile Kalite Karakterlerinin Stabilitesi Üzerine Araștırmalar. Türkiye Tahıl Sempozyumu, 6-9 Ekim 1987, Bursa, 443-454

Atlı A., 1999. Buğday ve Ürünleri Kalitesi. Orta Anadolu'da Hububat Tarımının Sorunları ve Çözüm Yolları Sempozyumu. 8-11 Haziran 1999, Konya. 498-506

Aydın N., Bayramoğlu H. O., Mut Z. ve Özcan H., 2005. Ekmeklik Buğday (Triticum aestivum L.) Çeșit ve Hatlarının Karadeniz Koșullarında Verim ve Kalite Özelliklerinin Belirlenmesi. AÜZF Tarım Bilimleri Dergisi, 11 (3):257-262

Aydoğan S., Göçmen Akçaçık A., Șahin M. ve Kaya Y., 2007. Ekmeklik buğday ( $T$. aestivum L.) genotiplerinde verim ve bazi kalite özellikleri arasindaki ilișkiler. Tarla Bitkileri Merkez Araștırma Enstitüsü Dergisi, Cilt 16. Sayı. 1-2

Demir İ., Yüce S., Tosun M., Sekin Y., Köse E. ve Sever C., 1999. İleri Ekmeklik Buğday Hatlarının Bazı Kalite Özelliklerinin Belirlenmesi Üzerinde Bir Çalıșma. Türkiye 3. Tarla Bitkileri Kongresi, 15-20 Kasım 1999, Adana, Cilt I Genel Tahıllar: s. $354-356$

Egesel C. Ö., Kahrıman F., Tayyar Ș. ve Baytekin H., 2009. Ekmeklik Buğdayda Un Kalite Özellikleri İle Dane Veriminin Karșılıklı Etkileșimleri ve Uygun Çeșit Seçimi. Anadolu Tarım Bilim Dergisi, 24(2):76-83

Elgün A., Türker S. ve Bilgiçli N., 2001. Tahıl ve Ürünlerinde Analitik Kalite Kontrolü. S. Ü. Ziraat Fakültesi Gıda Mühendisliği Bölümü Ders Notları, Konya Ticaret Borsası Yayın No:2, Konya

Ercan R., Seçkin R. ve Velioğlu S., 1988. Ülkemizde Yetiștirilen Bazı Ekmeklik Buğday Çeșitlerinin Kalitesi. Gıda 13 (2):107-114

Jusuf M, Rhayuningsih S.A., Wahyuni T.S. and Restuono J., 2008. Adaptasi dan stabilitas hasil klon harapan ubi jalar. Journal Penelitian Pertanian Tanaman Pangan, 27:37-41
Kahraman T., Șanal T. ve Öztürk i.., 2016. Determination of the Quality Parameters on Some Bread Wheat Genotypes in TrakyaMarmara Region of Turkey. 15th International Cereal and Bread Congress, April 18-21, 2016 İstanbul, Turkey. p:287

Kelly J. T., Bacon R. K. and Gbur E. E., 1995. Relationship of Grain Yield and Test Weight in Soft Red Winter Wheat. Cereal Research Communications, Vol: 23, Nos 1-2, p: 53-57

Schiller G. W., Ward A. B., Huang D. H. and Shellenberger J. A., 1967. Influence of protein content in wheat evaluation. Cereal Science Today, 12:372-376

Jusuf M, Rahayuningsih S.A., Wahyuni T.S. and Restuono J., 2008. Adaptasi dan stabilitas hasil klon harapan ubi jalar. Journal Penelitian Pertanian Tanaman Pangan, 27:37-41

Mut Z., Aydın N., Bayramoğlu N.O. and Özcan H., 2007. Bazı ekmelik buğday (Triticum aestivum L.) genotiplerinin verim ve bașlıca kalite özelliklerinin belirlenmesi. OMÜ Ziraat Fakültesi Dergisi, 22(2):193-201

Tayyar Ș., 2005. Biga koșullarında yetiștirilen bazı ekmeklik buğday (Triticum aestivum L.) çeșit ve hatlarının verim ve bazı kalite özelliklerinin saptanması. Akdeniz Üniversitesi, Ziraat Fakültesi Dergisi, 18(3):405-409

Toklu F., Yağbasanlar T. and Özkan H., 1999. Ekmeklik buğdayda (T. aestivum L.) hektolitre ağırlığı ile tanenin fiziksel ve kalite özellikleri arasındaki ilișkilerin saptanması üzerine bir araștırma. Türkiye III. Tarla Bitkileri Kongresi, 15-18 Kasım, Adana. 1999, 339-342

Yağdı K., 2004. Bursa koșullarında yetiștirilen ekmeklik buğday (Triticum aestivum L.) hatlarının bazı kalite özelliklerinin araștırıması. Uludağ Üni. Zir. Fak. Dergisi. 18 (1): 11-23

Yan W. and Kang M.S., 2002. GGE biplot analysis: A graphical tool for breeders, geneticists, and agronomists. CRC Press, Boca Raton, FL, 6388 